\title{
Pengaruh Attitude, Subjective Norm dan Perceived Behavior Control terhadap Entrepreneurial Intention
}

\author{
Laurensius Hansfel dan Ida Puspitowati \\ Program Studi Manajemen Fakultas Ekonomi \\ Universitas Tarumanagara \\ Email: laurensiush@gmail.com
}

\begin{abstract}
The purpose of this research was to determine whether there is an influence of attitudes on entrepreneurial intentions, subjective norms on entrepreneurial intentions and perceived behavioral control on entrepreneurial intentions for Bachelor of Economics and Business Faculty of Tarumanagara University. The design used in this study is a casual type quantitative method, which is a simple research design that uses purposive sampling as the method and the researcher took a total sample of 150 respondents and this researcher used SmartPLS. The results of this study indicate that the attitudes and behavioral control perceived positive and significant influence on entrepreneurial intentions, but subjective norms do not affect entrepreneurial intentions for Bachelor of Economics and Business Faculty of Tarumanagara University.
\end{abstract}

Keywords: Attitude, Subjective Norm, Perceived Behavioral Control, Entrepreneurial Intention

Abstrak: Tujuan dari penelitian ini adalah untuk mengetahui apakah terdapat pengaruh sikap terhadap intensi berwirausaha, norma subyektif terhadap intensi berwirausaha dan kontrol perilaku yang dirasakan terhadap intensi berwirausaha bagi Sarjana Fakultas Ekonomi dan Bisnis Universitas Tarumanagara. Desain yang digunakan dalam penelitian ini adalah metode kuantitatif berjenis kasual, yang merupakan desain penelitian yang sederhana yang menggunakan purposive sampling sebagai metodenya dan peneliti mengambil jumlah sampel sebanyak 150 responden dan peneliti ini menggunakan SmartPLS. Hasil penelitian ini menunjukan bahwa sikap dan kontrol perilaku yang dirasakan berpengaruh postif dan signifikan terhadap intensi berwirausaha, akan tetapi norma subyektif tidak berpengaruh terhadap intensi berwirausaha bagi Sarjana Fakultas Ekonomi dan Bisnis Universitas Tarumanagara.

Kata Kunci: Sikap, Norma Subyektif, Kontrol Perilaku yang Dirasakan, Intensi Berwirausaha

\section{LATAR BELAKANG}

Permasalahan tingginya tingkat angkatan kerja dan minimnya jumlah lapangan pekerjaan di Indonesia disebabkan karena ketergantungan individu terhadap Pemerintah. Individu pada saat ini lebih condong memilih untuk bekerja pada perusahaan swasta maupun Pemerintah dibandingkan membuat atau menjalankan usaha secara mandiri yang dikarenakan individu memiliki pemikiran adanya jaminan hari tua serta adanya pendapatan setiap bulan yang sudah pasti. Kondisi ini juga diperburuk dikarenakan dengan adanya situasi persaingan global akan mempertemukan lulusan perguruan tinggi dalam negeri dengan pesaing dari lulusan perguruan tinggi asing secara bebas.

Dirangkum dari Warta Ekonomi (2019) Indonesia membutuhkan sedikitnya 4 juta wirausahawan baru untuk mendorong perekonomian Indonesia. Pada saat ini, rasio 
wirausahawan sebesar $3,1 \%$ dari total populasi penduduk (8,06 juta orang). Menurut Airlangga Hartanto, Menteri Perindustrian, meskipun rasio tersebut sudah melampaui standar global yaitu $2 \%$, Indonesia masih perlu menambahkannya lagi untuk mengejar standar negara tetangga seperti Singapura di angka 7\% dan Malaysia di angka 5\%. Oleh sebab itu, untuk menjadikan Indonesia negara maju, Pemerintah terus mendorong pertumbuhan wirausaha termasuk UMKM serta meningkatkan produktivitas daya saing di revolusi industri 4.0 atau di era digital. (www.wartaekonomi.co.id, 2019).

Mengingat peningkatan minimnya jumlah lapangan pekerjaan yang tersedia pada situasi saat ini dikarenakan pandemi covid-19, menyebabkan banyaknya pengangguran yang terkena imbas Pemutusan Hubungan Kerja dari perusahaan, di samping itu dengan kebijakan dari Pemerintah pembatasan sosial berskala besar yang berdampak pada peningkatan jumlah pengangguran. Selain karena adanya pandemi yang berdampak minimnya jumlah lapangan pekerjaan yang tersedia, peningkatan ini juga dipengaruhi karena adanya faktor lain seperti masalah pertumbuhan penduduk yang sangat cepat serta soft skill dari masyarakat kurang berkembang dan menyebabkan kalah bersaing, serta pendidikan yang terbatas. Menurut data dari Badan Pusat Statistik (BPS), jumlah angkatan kerja di Indonesia pada bulan Agustus 2019 sebanyak 133,56 juta orang (www.bps.go.id, 2019).

Jiwa kewirausahaan juga didukung oleh minat berwirausaha, dimana minat berwirausaha tumbuh karena adanya rasa ketertarikan terhadap kegiatan berwirausaha untuk menciptakan suatu usaha yang bermanfaat. Minat berwirausaha merupakan suatu gejala untuk memusatkan perhatian serta ketertarikan terhadap wirausaha dan adanya rasa senang terhadap berwirausaha, serta adanya keinginan atau dorongan untuk berwirausaha (Maryanti, 2017). Individu yang memiliki minat berwirausaha juga dikarenakan adanya faktor keinginan berprestasi, sifat individu yang penasaran, berani dalam mengambil keputusan dan menanggung resiko, pendidikan yang cukup serta pengalaman yang telah ada.

Deputi Sumber Daya Manusia Kementerian Koperasi dan UKM, Prakoso BS, mengharapkan agar lulusan perguruan tinggi membuka usaha dibandingkan mencari pekerjaan. Data Kementerian Koperasi dan UKM menunjukkan, saat ini jumlah wirausaha di Indonesia baru mencapai 1,65 persen atau sekitar 3,7 juta penduduk, untuk menjadi negara maju jumlah wirausahawan diharuskan minimal lebih dari $2 \%$ dari total penduduk, oleh karena itu dibutuhkan sekitar 2 juta wirausahawan baru. Bertambahnya wirausaha dari kalangan pemuda melalui lulusan perguruan tinggi dan pemberdayaan ekonomi rakyat diharapkan bisa memecahkan masalah pengangguran dan kemiskinan (www.kompas.com, 2017).

Minat berwirausaha sangatlah penting untuk dimiliki lulusan perguruan tinggi, jika individu tersebut tidak memiliki attitude (sikap) seperti tidak mudah putus asa, mengambil resiko, memiliki rasa percaya diri yang tinggi, kreatif dan inovatif, serta kemampuan memimpin yang dapat tercipta dengan sendirinya maka individu tersebut akan sulit untuk memiliki minat berwirausaha. Niat untuk berwirausaha dapat dipengaruhi oleh beberapa faktor seperti attitude (sikap), subjective norm (norma subyektif), dan perceived behavior control (kontrol perilaku yang dirasakan).

Niat atau intensi merupakan dasar individu untuk berwirausaha dengan diimbangi pada keyakinan terhadap dirinya akan berdampak baik bagi terciptanya wirausahawan baru. Menurut Thompson (2009) entrepreneurial intention (intensi berwirausaha) adalah keyakinan yang diakui sendiri oleh individu untuk mendirikan usaha baru dan secara sadar berencana akan melakukannya di masa depan. Dari pernyataan ini dapat disimpulkan keyakinan pada diri sendiri dapat mendirikan usaha baru dan berencana untuk melakukan beberapa kali di masa depan, Intensi didukung juga dengan Theory of Planned Behavior (TPB) menurut Ajzen (1991) menjelaskan bahwa perilaku yang direncanakan berasal dari hasil masingmasing individu yang dikombinasikan antara attitude (sikap), subjective norm (norma 
subyektif), dan perceived behavior control (kontrol perilaku yang dirasakan) di lingkungan sekitar individu.

Menurut Linan dan Chen (2006) attitude (sikap) menilai sejauh mana individu memiliki penilaian pribadi positif atau negatif untuk menjadi seorang pengusaha dirasakan agar dapat terbentuknya niat untuk berwirausaha terhadap individu. Menurut Ajzen (1991), Subjective norm (norma subyektif) merupakan bentuk dukungan sosial yang didapatkan individu untuk terlibat atau menghindari perilaku tertentu dan dapat dikembangan berdasarkan pengaruh orang-orang terdekat seperti keluarga, teman, dan rekan. Menurut Rachmawan dkk. (2015) rceived behavior control (kontrol perilaku yang dirasakan) dari individu tersebut dikarenakan adanya suatu persepsi terhadap suatu tingkat kesulitan atau kemudahan individu untuk menjadi seorang wirausaha dapat memunculkan niat untuk membangun suatu usaha.

Menurut Rektor Universitas Tarumanagara, Prof. Agustinus Purna Irawan, Universitas Tarumanagara menjadi salah satu universitas yang turut dalam membangun jiwa entrepreneur pada anak didiknya. Dengan salah satu acara yang dilaksanakan yaitu Entrepreneur Week diharapkan membantu mahasiswa membangun mental yang kuat untuk bersiap menghadapi persaingan yang ketat di masa yang akan datang dan menghasilkan calon entrepreneur Indonesia yang matang serta siap dalam bersaing. Dengan begitu, mahasiswa tidak akan kaget saat lulus menjadi sarjana dan telah siap dalam membangun suatau usaha baru (www.liputan6.com, 2020)

\section{KAJIAN TEORI}

Attitude (Sikap). Menurut Ajzen (1991) attitude (sikap) adalah sejauh mana individu tersebut mempunyai evaluasi pribadi yang positif ataupun negatif untuk menjadi seorang pengusaha.

Menurut Muthmainah dan Cholil (2015) attitude (sikap) adalah kecenderungan psikologis terhadap pihak-pihak tertentu yang mempunyai karakteristik yang evaluatif, apakah menguntungkan atau tidak menguntungkan, serta perilaku tertentu yang terdiri dari kesesuaian karir, rasionalitas pendapat, minat, harapan untuk tingkat kepuasan dan kecenderungan bagi perilaku.

\section{Subjective Norm (Norma Subyektif)}

Menurut Nilsson, Borgstede, dan Biel (2004) subjective norm (norma subyektif) adalah norma ide yang menjelaskan mengenai kepercayaan seseorang untuk merujuk kepada pengaruh pihak lain dalam berperilaku dengan cara tertentu dan termotivasi untuk referensi tertentu.

Menurut Ajzen (1991, h. 195) mendefinisikan subjective norm (norma subyektif) adalah "a subjective norm is a form of social pressure placed on an individual to engage or avoid certain behavior and developed based on the influence of the people around the individual such as family, friends and colleagues". dapat diartikan subjective norm (norma subyektif) merupakan suatu bentuk tekanan sosial pada seseorang untuk terlibat atau tidak terhadap perilaku dan dapat dikembangankan dengan dasar pengaruh orang disekitarnya seperti keluarga.

Perceived Behavior Control (Kontrol Perilaku Yang Dirasakan). Menurut Rachmawan, Lizar dan Mangundjaya (2015) perceived behavior control (kontrol perilaku yang dirasakan) didefinisikan sebagai persepsi tentang kemudahan ataupun kesulitan dalam menjadi seorang wirausahawan.

Menurut Mafabi dkk., (2017) perceived behavior control (kontrol perilaku yang dirasakan) adalah keadaan psikologis individu tentang kemampuan dan motivasi seseorang untuk terlibat dalam sebuah perilaku termasuk keyakinan dalam mengelola gangguan maupun hambatan perilaku seperti waktu, biaya, dan ketersediaan. 
Entrepreneurial Intention (Intensi Berwirausaha). Menurut Murugesan dan Jayavelu (2015) entrepreneurial intention (intensi berwirausaha) adalah momen cerminan yang mengarahkan sebuah tindakan orang kepada suatu pengembangan atau peningkatan suatu konsep baru dalam memulai bisnis.

Menurut Thompson (2009) entrepreneurial intention (intensi berwirausaha) adalah keyakinan yang diakui individu bahwa mereka sungguh berniat dalam membangun sebuah usaha bisnis baru dan secara sadar berencana akan melakukannya di masa depan.

Kaitan antara attitude (sikap) dan entrepreneurial intention (intensi berwirausaha). Menurut Ferreira dkk. (2012) pengaruh positif antara attitude (sikap) terhadap entrepreneurial intention (intensi berwirausaha) ini memberikan informasi bahwa entrepreneurial intention (intensi berwirausaha) akan semakin kuat apabila mahasiswa dibekali pengetahuan ilmu bisnis, pengembangan attitude (sikap) serta pembangunan mental yang sedemikian baik sehingga mereka akan lebih mempunyai kepercayaan diri untuk memulai atau menjalankan sebuah usaha.

H1: Attitude memiliki pengaruh yang positif terhadap entrepreneurial intention.

Kaitan antara subjective norm (norma subyektif) dan entrepreneurial intention (intensi berwirausaha). Menurut Aliyu dan Ahmed (2015) menyatakan subjective norm (norma subyektif) memiliki pengaruh yang positif terhadap entrepreneurial intention (intensi berwirausaha), bahwa siswa cenderung menjadi wiraswasta setelah lulus ketika kontak langsung mereka mendukung untuk menjadi wirausaha.

H2: Subjective norm (norma subyektif) memiliki pengaruh yang positif terhadap entrepreneurial intention (intensi berwirausaha).

Kaitan antara perceived behavior control (kontrol perilaku yang dirasakan) dan entrepreneurial intention (intensi berwirausaha). Menurut Solesvik (2012), bahwa perceived behavior control (kontrol perilaku yang dirasakan) mempunyai kaitan yang positif dengan kepercayaan pada suatu perilaku yang akan dilakukan oleh individu. Semakin kuat keyakinan individu untuk mampu memulai atau menjalankan suatu usaha baru, semakin kuat juga intensi untuk berwirausaha dari seorang individu.

H3: Perceived behavior control memiliki pengaruh yang positif terhadap entrepreneurial intention.

Attitude (sikap), subjective norm (norma subyektif), dan perceived behavior control (kontrol perilaku yang dirasakan) merupakan suatu hal yang penting terhadap entrepreneurial intention (intensi berwirausaha), dikarenakan dengan mempelajari ketiga hal tersebut, seseorang yang akan membuat atau akan menjalankan sebuah usaha menjadi lebih mengetahui lebih banyak mengenai hal apa saja yang perlu dilakukan dalam menjalankan sebuah usaha.

Subjective norm (norma subyektif) dianggap penting karena jika adanya pengaruh atau dukungan dari orang terdekat seperti keluarga dan kerabat akan membuat individu tersebut menjadi memiliki motivasi untuk menjalankan sebuah usaha maka dari itu sebuah dukungan dianggap penting untuk membuat atau menjalankan sebuah usaha.

Perceived behavior control (kontrol perilaku yang dirasakan) adalah salah satu aspek yang mempengaruhi entrepreneurial intention (intensi berwirausaha) karena adanya dukungan dari dalam diri individu untuk merasakan suatu tingkat kesulitan atau kemudahan untuk menjadi seorang wirausaha atau menjalankan usaha semakin individu tersebut merasa mudah dalam menjalankan usaha atau menjadi seorang wirausahawan maka semakin besar pula individu tersebut memiliki niat berwirausaha. 
Berdasarkan kerangka pemikiran yang telah dilakukan sebelumnya, maka peneliti memilih untuk mengambil tiga (3) variabel independen yaitu attitude (sikap), subjective norm (norma subyektif), perceived behavior control (kontrol perilaku yang dirasakan), Serta satu (1) variabel dependen yaitu entrepreneurial intention (intensi berwirausaha).

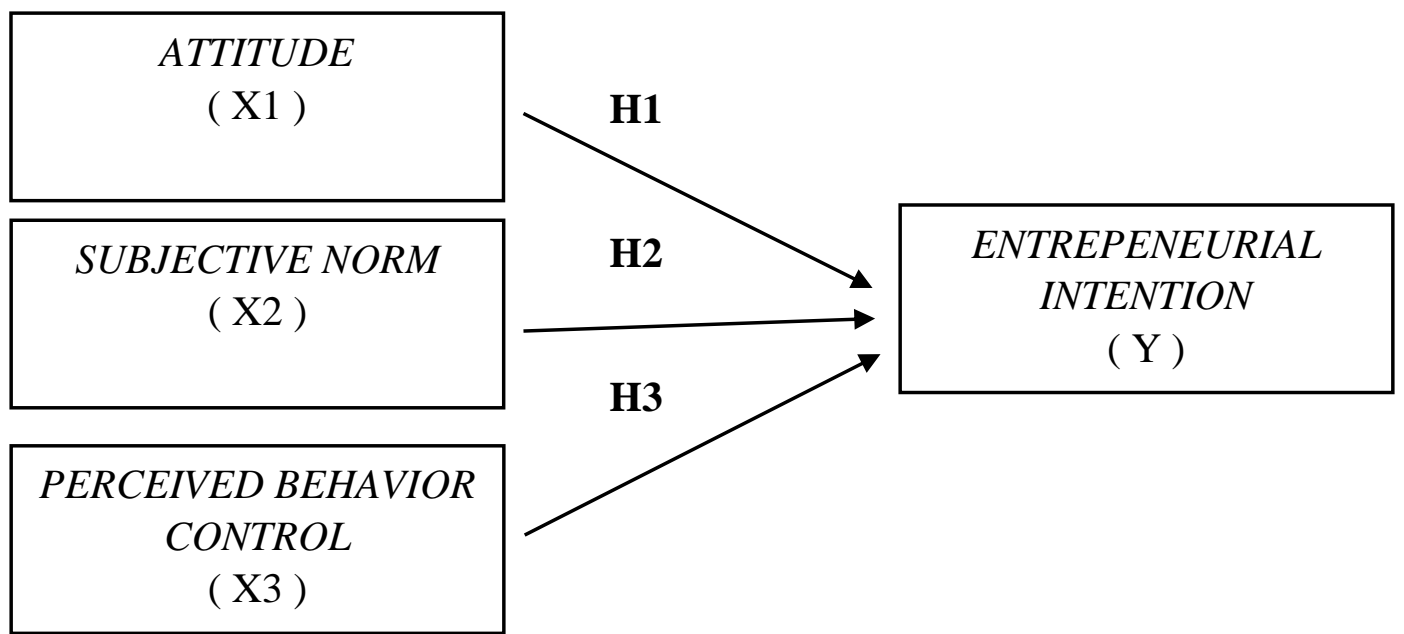

Gambar 1. Model Penelitian

\section{METODOLOGI}

Dalam penelitian ini menggunakan desain penelitian yaitu penelitian kuantitatif berjenis kasual. Menurut Sugiyono (2013) penelitian kuantitatif merupakan penelitian yang datanya diukur menggunakan skala numerik (angka) yang dapat dianalisis menggunakan metode statistik. Menurut Sugiyono (2012) penelitian kausal merupakan metode penelitian yang mengumpulkan data untuk melihat sebuah hubungan sebab akibat pada variabel independen (X) terhadap variabel dependen (Y) dengan tujuan menggambarkan dan menjelaskan suatu fenomena. Penelitian ini bertujuan untuk mengetahui hubungan antara intensi kewirausahaan yang muncul dikarenakan oleh faktor-faktor yang berkaitan dengan individu.

Dalam penelitian ini, pemilihan sampel menggunakan teknik purposive sampling yang dimana teknik pemilihan berdasarkan subjek yang selanjutnya dijadikan sampel pada penelitian ini yaitu Sarjana Fakultas Ekonomi dan Bisnis Universitas Tarumanagara. Teknik pemilihan sampel pada penelitian ini menggunakan metode nonprobability sampling dengan teknik purposive sampling. Menurut Aritonang (2005) pada teknik purposive sampling, unsur-unsur dari populasi yang akan ditentukan digunakan untuk sampel yang berdasarkan pada tujuan penelitian yang dilakukan.

Sampel pada penelitian ini merupakan Sarjana Fakultas Ekonomi dan Bisnis Universitas Tarumanagara tahun 2018, 2019, dan 2020. Jumlah sampel yang akan diambil sebanyak 150 responden.

Tabel 1. Indikator Pengukuran Variabel

\begin{tabular}{|c|c|c|}
\hline Variabel & Jumlah Indikator & Sumber \\
\hline Attitude & 5 pernyataan & \multirow{2}{*}{$\begin{array}{c}\text { Debarliev dkk. } \\
(2015)\end{array}$} \\
\hline Subjective Norm & 3 pernyataan & \\
\hline Perceived Behavior Control & 6 pernyataan & \\
\hline
\end{tabular}


Pada penelitian yang dilakukan ini menggunakan metode analisis data dengan menggunakan software SmartPLS versi 3.3.2 yang dirancang untuk memperkirakan persamaan struktural. Dengan software tersebut, data akan dievaluasi melalui outer model serta inner model. Pada outer model terdiri dari pengujian validitas dan reliabilitas. Pada inner model terdiri dari uji $\mathrm{R}$ square $\left(\mathrm{R}^{2}\right)$, uji $\mathrm{Q}$ square $\left(\mathrm{Q}^{2}\right)$, uji Goodness of Fit $(\mathrm{GoF})$, dan uji hipotesis.

\section{HASIL UJI STATISTIK}

Berdasarkan hasil Loading Factor, semua indicator pada loading factor telah memenuhi syarat untuk valid atau terpenuhi dengan nilai diatas 0,6. Berdasarkan hasil Average Variance Extracted (AVE) dan Cross Loading Factor, dapat disimpulkan bahwa setiap variabel memenuhi kriteria validitas konvergen dan validitas diskriminan. Selanjutnya berdasarkan hasil Composite Reliability, dapat disimpulkan juga bahwa setiap variabel yang digunakan pada skripsi ini dinilai reliabel.

Berdasarkan hasil dari pengujian $\mathrm{R}$ square, digunakan nilai adjusted $\mathrm{R}$ square yaitu sebesar 0,568. Hasil ini menunjukkan pengaruh variabel attitude, subjective norm, dan perceived behavior control terhadap entrepreneurial intention adalah sebesar 56,8\%. Sedangkan 43,2\% entrepreneurial intention dipengaruhi oleh variabel lain yang tidak ada pada penelitian ini. Maka dapat disimpulkan uji $\mathrm{R}$ square pada penelitian ini memiliki pengaruh yang tergolong sedang. Berdasarkan hasil pengujian $\mathrm{Q}$ square, nilai dari $\mathrm{Q}$ square adalah sebesar 0,325. Nilai ini menunjukkan bahwa attitude, subjective norm, dan perceived behavior control memiliki relevansi prediktif model penelitian yang bersifat sedang.

Hasil uji Goodness of Fit (GoF) sebesar 0,603 dan dapat disimpulkan bahwa kategori yang digunakan merupakan kategori penelitian yang tergolong besar. Hasil uji hipotesis dapat dilihat pada Tabel 2.

Tabel 2. Hasil Pengujian Hipotesis

\begin{tabular}{|c|c|c|c|}
\hline Variabel & $\begin{array}{c}\text { Original } \\
\text { Sample }\end{array}$ & T-statistics & P-values \\
\hline Attitude $\rightarrow$ Entrepreneurial Intention & 0,307 & 2,150 & 0,016 \\
\hline $\begin{array}{c}\text { Subjective Norm } \rightarrow \text { Entrepreneurial } \\
\text { Intention }\end{array}$ & 0,173 & 1,362 & 0,087 \\
\hline $\begin{array}{c}\text { Perceived Behavior Control } \rightarrow \\
\text { Entrepreneurial Intention }\end{array}$ & 0,324 & 2,675 & 0,004 \\
\hline
\end{tabular}

Berdasarkan hasil pengujian variabel variabel attitude terhadap entrepreneurial intention, dapat dikatakan bahwa $\mathrm{H} 1$ diterima karena attitude memiliki nilai $\mathrm{t}$ statistics sebesar 2,150 dan nilai $\mathrm{p}$ values sebesar 0,016. Nilai t statistics tersebut lebih besar dari pada 1,645 dan nilai $\mathrm{p}$ values lebih kecil dari 0,05 atau 5\%. Sehingga dapat dikatakan attitude berpengaruh secara positif terhadap entrepreneurial intention.

Berdasarkan hasil pengujian variabel subjective norm terhadap variabel entrepreneurial intention, dapat dikatakan bahwa $\mathrm{H} 2$ ditolak karena subjective norm memiliki nilai t statistics sebesar 1,362 dan nilai $\mathrm{p}$ values sebesar 0,087. Nilai t statistics tersebut lebih kecil dari pada 1,645 dan nilai $\mathrm{p}$ values lebih besar dari 0,05 atau 5\%. Sehingga dapat dikatakan subjective norm ditolak atau tidak signifikan terhadap entrepreneurial intention. 
Berdasarkan hasil pengujian variabel perceived behavior control terhadap variabel entrepreneurial intention, dapat dikatakan bahwa $\mathrm{H} 3$ diterima karena sikap memiliki nilai $\mathrm{t}$ statistics sebesar 2,675 dan nilai p values sebesar 0,004. Nilai t statistics tersebut lebih besar dari pada 1,645 dan nilai p values lebih kecil dari 0,05 atau 5\%. Sehingga dapat dikatakan perceived behavior control berpengaruh secara positif terhadap entrepreneurial intention.

Berdasarkan penjelasan mengenai uji hipotesis maka dapat disimpulkan bahwa variabel attitude dan perceived behavior control memiliki pengaruh yang positif terhadap entrepreneurial intention namun akan tetapi pada variabel subjective norm tidak berpengaruh terhadap entrepreneurial intention pada Sarjana Fakultas Ekonomi dan Bisnis Universitas Tarumanagara.

\section{DISKUSI}

Berdasarkan hasil analisis data dapat disimpulkan bahwa $\mathrm{H} 1$ diterima variabel attitude berpengaruh positif terhadap entrepreneurial intention bagi Sarjana Fakultas Ekonomi dan Bisnis Universitas Tarumanagara. Penelitian ini juga sejalan dengan penelitian yang dilakukan Debarliev dkk. (2015) terhadap 440 kuesioner valid yang dibagikan kepada mahasiswa di Universitas Macedonia dengan menggunakan metode hierarki regresi menyimpulkan bahwa attitude (sikap) berpengaruh terhadap entrepreneurial intention (intensi berwirausaha). Oleh sebab itu, bahwa attitude (sikap) merupakan sebuah attitude (sikap) dan penilaian yang bersifat evaluatif baik tentang positif (menguntungkan) atau negatif (merugikan) individu terhadap suatu tindakan terutama untuk menjadi seorang pengusaha dan didapatkan kesimpulannya attitude (sikap) dinilai berhubungan dengan entrepreneurial intention (intensi berwirausaha) pada Sarjana Fakultas Ekonomi dan Bisnis Universitas Tarumanagara dan apabila Sarjana tersebut telah mempunyai cukup pengetahuan mengenai attitude (sikap) yang dibutuhkan serta wawasan yang cukup untuk menjadi wirausahawan ataupun memulai sebuah usaha baru, oleh sebab itu menumbuhkan intensi pada individu tersebut untuk menjadi seorang wirausahawan.

Berdasarkan hasil analisis data dapat disimpulkan bahwa $\mathrm{H} 2$ ditolak sehingga subjective norm tidak memiliki pengaruh positif terhadap entrepreneurial intention Sarjana Fakultas Ekonomi dan Bisnis Universitas Tarumanagara. Hasil dari pengujian variabel subjective norm (norma subyektif) pada penelitian ini dinilai sejalan dengan penelitian yang dilakukan oleh Solesvik (2012) terhadap 321 mahasiswa di 3 (tiga) Universitas di Ukraina dengan menggunakan hirarki multipel regresi, dalam penelitian tersebut memberikan pendapat dan yang sama dengan menggunakan indikator entrepreneurial intention (intensi berwirausaha) menjelaskan bahwa subjective norm (norma subyektif) tidak signifikan dan tidak berpengaruh terhadap entrepreneurial intention (intensi berwirausaha). Oleh Sebab itu, bahwa subjective norm (norma subyektif) adalah suatu persepsi seseorang berdasarkan dari pengaruh orangorang terdekat (keluarga dan atau teman dekat) atau persepsi terhadap sejauh mana lingkungan sosial yang cukup berpengaruh untuk melakukan atau tidak melakukan, setuju maupun tidak setuju terhadap suatu tindakan yang akan dilakukan, sehingga bisa menjadi suatu motivasi maupun tidak bagi seorang wirausahawan / pengusaha dan dapat disimpulkan bahwa subjective norm (norma subyektif) tidak memiliki pengaruh yang signifikan terhadap entrepreneurial intention (intensi berwirausaha) ini diakibatkan beberapa faktor yang menyebabkan hal tersebut, misalnya seperti kurangnya faktor-faktor dalam dukungan keluarga, teman, maupun orang yang dianggap penting yang mungkin kurang mendukung individu tersebut untuk menjadi seorang wirausahawan atau membangun usaha sendiri.

Berdasarkan hasil analisis data dapat disimpulkan bahwa $\mathrm{H} 3$ diterima sehingga perceived behavior control berpengaruh positif terhadap entrepreneurial intention pada Sarjana Fakultas Ekonomi dan Bisnis Universitas Tarumanagara. Penelitian ini juga sejalan dengan penelitian yang dilakukan oleh Muhammad (2015) terhadap 205 sampel kuesioner yang valid 
yang disebarkan kepada mahasiswa di International Islamic Universitas Malaysia dengan menggunakan penelitian metode empiris yang dibagikan secara acak memberikan pendapat bahwa indikator perceived behavior control (kontrol perilaku yang dirasakan) memiliki pengaruh yang positif terhadap entrepreneurial intention (intensi berwirausaha). Oleh sebab itu, bahwa perceived behavior control (kontrol perilaku yang dirasakan) dapat diartikan sebagai suatu persepsi individu terhadap suatu tingkat kesulitan atau kemudahan bagi individu untuk menjadi seorang wirausaha pada individu, dan dapat disimpulkan bahwa perceived behavior control (kontrol perilaku yang dirasakan) berhubungan dengan entrepreneurial intention (intensi berwirausaha) pada Sarjana Fakultas Ekonomi dan Bisnis Universitas Tarumanagara dan apabila Sarjana tersebut telah mempunyai cukup pengetahuan mengenai perceived behavior control (kontrol perilaku yang dirasakan) yang dibutuhkan serta wawasan yang cukup untuk menjadi wirausahawan ataupun memulai sebuah usaha baru, oleh sebab itu menumbuhkan entrepreneurial intention (intensi berwirausaha) pada individu tersebut untuk menjadi seorang wirausahawan.

\section{PENUTUP}

Berdasarkan hasil pengujian yang telah dilakukan, diperoleh kesimpulan yaitu variabel attitude dan perceived behavior control berpengaruh positif terhadap entrepreneurial intention pada Sarjana Fakultas Ekonomi dan Bisnis Universitas Tarumanagara. Sedangkan variabel Subjective norm tidak berpengaruh dan tidak signifikan terhadap entrepreneurial intention pada Sarjana Fakultas Ekonomi dan Bisnis Universitas Tarumanagara

\section{DAFTAR PUSTAKA}

Aritonang, L. R. (2005). Kepuasan pelanggan. Jakarta: PT. Gramedia Pustaka Utama.

Ajzen, I. (1991). The theory of planned behavior. Organizational behavior and human decision processes, 50(2), 179-211.

BPS. (2019) Keadaan Angkatan Kerja di Indonesia (Retrieved from: www.bps.go.id/29-112019)

Debarliev, S., Janeska-Iliev, A., Bozhinovska, T., \& Viktorija, I. (2015). Antecedents of entrepreneurial intention: Evidence from Republic of Macedonia. Business and Economic Horizons (BEH), 11, 143-161.

Ferreira, J. J., Raposo, M. L., Rodrigues, R. G., Dinis, A., \& Paço, A. D. (2012). A model of entrepreneurial intention: An application of the psychological and behavioral approaches. Journal of Small Business and Enterprise Development, 19(3), 424-440.

Kompas. (2017) Pemerintah Terus Motivasi Pemuda untuk Jadi Wirausahawan (Retrieved from: https://money.kompas.com/11-02-2017)

Liñán, F., \& Chen, Y. W. (2006). Testing the entrepreneurial intention model on a twocountry sample. 6(7), 1-28

Liputan 6 (2020) Perkuat Mental Mahasiswa Penggiat Startup, Untar Gelar Entrepreneur Week (Retreived from: www.liputan6.com/28-01-2020)

Murugesan, R., \& Jayavelu, R. (2015). Testing the impact of entrepreneurship education on business, engineering and arts and science students using the theory of planned behaviour. Journal of Entrepreneurship in Emerging Economies, 7(3), 256-275.

Mafabi, S., Nasiima, S., Muhimbise, E. M., Kasekende, F., \& Nakiyonga, C. (2017). The mediation role of intention in knowledge sharing behavior. Vine Journal of Information and Knowledge Management Systems, 47(2), 172-193

Muhammad, A. D., Aliyu, S., \& Ahmed, S. (2015). Entreprenuerial Intention Among Nigerian University Students. American Journal of Business Education (AJBE), 8(4), 239-248. 
Muthmainah \& Cholil, M. (2015). Analysis of Attitude, Experience, Subjective Norm and Behavioral Control on The Entrepreneurial Intention and Behavior: A Case Study toward The Pawners of Sharia Pawnshop of Surakarta Branch Office, Central Java, Indonesia. International Journal of Information, Business and Management, 7(2), 6376.

Nilsson, A., von Borgstede, C., \& Biel, A. (2004). Willingness to accept climate change strategies: The effect of values and norms. Journal of environmental psychology, 24(3), 267-277.

Rachmawan, A., Lizar, A. A., \& Mangundjaya, W. L. (2015). The role of parent's influence and self-efficacy on entrepreneurial intention. The journal of developing areas, 49, 417-430.

Solesvik, M. Z. (2012). Entrepreneurial motivations and intentions: investigating the role of education major. Investigating the Role of Education Major, 55, 253-271.

Sri Maryanti (2017). Manajemen Usaha Kecil. Yogyakarta: Badan Penerbit Deepublish

Sugiyono. (2012). Metode Penelitian Kuantitatif Kualitatif dan R\&D. Bandung: Alfabeta.

. (2013). Metode Penelitian Pendidikan Pendekatan Kuantitatif, Kualitatif, dan $R \& D$. Bandung: Alfabeta.

Thompson, E. R. (2009). Individual entrepreneurial intent: Construct clarification and development of an internationally reliable metric. Entrepreneurship theory and practice, 3(3), 669-694.

Warta Ekonomi. (2018) Jumlah Pengusaha Indonesia Masih Tertinggal dari Singapura (Retrieved from: www.wartaekonomi.co.id/26-11-2018) 